\title{
Resilient companies in the time of Covid-19 pandemic: a case study approach
}

\author{
Chiara Acciarini and Paolo Boccardelli \\ Business and Management, Luiss University, Rome, Italy and \\ Luiss Business School, Rome, Italy, and \\ Mario Vitale \\ Luiss Business School, Rome, Italy
}

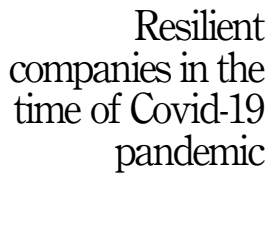

Received 4 March 2021

Revised 11 May 2021

Accepted 11 May 2021

\begin{abstract}
Purpose - The Covid-19 pandemic represents an extraordinary and unpredictable event influencing the whole economy and society. Using a case study approach, the authors explored how big companies operating in Italy were able to respond to the crisis to ensure business continuity. Therefore, the authors discussed different business disruptions caused by Covid-19; in addition, they developed an integrated policy framework in which they proposed specific strategic responses for increasing the level of organizational resilience. The aim of the paper is to discuss and reflect on the ability of specific companies to increase their level of organizational resilience when unexpected events happen.

Design/methodology/approach - The authors conducted semi-structured interviews with target CEOs of four major companies operating in Italy in different industries. Especially, the authors focused on multiutilities, media and communications, investment banking and mobile telecommunications. The interviews were based on questions dealing with Covid-19 implications and strategic responses to navigate this complex scenario.

Findings - Based on the CEOs' contributions, the authors presented short-term actions and long-term strategies planned and implemented by each Italian company. In particular, the authors emphasized similarities and dissimilarities in terms of strategic responses and future business development.

Originality/value - The analysis of practical cases was helpful for increasing their knowledge on organizational resilience and for providing the managerial community with a policy framework to navigate unexpected events like the Covid-19 pandemic.
\end{abstract}

Keywords Covid-19, Organisational resilience, Digital, Technology, Strategy

Paper type Research paper

\section{Introduction}

The in-progress Covid-19 pandemic is generating enormous threats that will change the whole society and economy forever. At the time of this article, more than 159 million confirmed cases and 3.3 millions of deaths are recorded around the world (World Health Organization, 2021). If we look at the economic side of the effects, it is estimated that the virus could totally cost the global economy between US\$8.1 and US\$15.8 trillion globally (Schwab, 2020). At the same time, the International Monetary Fund expects that the global economy could grow up to $5.5 \%$ in 2021 , with an expansion of $4.2 \%$ in 2022 . The worst scenario related to the job market forecasts serious disruptive effects in terms of global unemployment; in fact, it is expected to increase by 24.7 million (International Labor Organization, 2020). Only in China - where the first virus case happened in November 2019 - car sales plummeted $80 \%$ and passenger traffic dropped 85\% from normal levels (Bloomberg, 2020); in addition, the

(C) Chiara Acciarini, Paolo Boccardelli and Mario Vitale. Published by Emerald Publishing Limited. This article is published under the Creative Commons Attribution (CC BY 4.0) licence. Anyone may reproduce, distribute, translate and create derivative works of this article (for both commercial and noncommercial purposes), subject to full attribution to the original publication and authors. The full terms of this licence may be seen at http://creativecommons.org/licences/by/4.0/legalcode

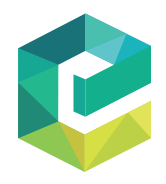

Journal of Entrepreneurship and Public Policy 
number of departures from Chinese ports has decreased by $20 \%$, according to Haren and Simchi-Levi (2020). Thus, the Covid-19 emergency affects every industry: tourism could lose at least US\$1.2 trillion (UNCTAD, 2020) and the number of scheduled flights worldwide reduced by around 50\% in August 2020 compared to August 2019 (Statista, 2020). Furthermore, the industrial production index dropped by 37.5 last February, and it is considered "the lowest reading since 2004" by UNCTAD. In Europe, after a decrease in March and April, industrial production is increased by $9.1 \%$ in June 2020 (Eurostat, 2020). In relation to the transaction market, the $\mathrm{CBOE}$ volatility index [1] touched over 80 points on March 2020 (Baek et al., 2020); normally, its value travels around 20 points. Moreover, the virus is making the diversification strategy ineffective; also, the merger and acquisition (M\&A) market is affected by the deterioration of capital markets and the real economy, resulting in several pulled or delayed deals. Even the consequences involving the globalization theories are widely discussed; the pandemic is already pushing the countries into nationalist narratives. For instance, the USA could consider China a real threat, while the Chinese could interpret the American measures and feelings as racial. For decades, markets have become open, the supply chains global, middle classes have been reversed and new connections have been created. More recently, flows of information, ideas, money, jobs and people are challenged. In addition, there is a tightening of immigration rules, supply chains get shorter, and new barriers to trade and investment emerge.

If we look at the social side of the virus effects, vulnerable individuals, people living in poverty conditions, older persons and people with disabilities are hit, as recently suggested by the United Nations (2020). With regards to Africa, over 4 million confirmed cases are recording up (Africa Union, 2021); especially, the pandemic represents a serious threat in places like South Sudan where any place in intensive care treatment is present. Furthermore, people living in crowded slums between dirt and violence are particularly at risk. More in general, we need to consider that in some countries there are no sufficient numbers of hospital beds. Last but not least, the psychological impact deriving from the application of national measures (e.g. quarantine) is considerable; in addition to psychological stress (Scott et al., 2020), depressive symptoms, fear and insomnia (Torales et al., 2020), the association between alcohol, drug abuse and suicide and unemployment is significant (Continetti, 2020).

As discussed, the Covid-19 is increasing the fragility of the whole system and it is also changing the way in which companies and institutions create, share and capture value. The aim of this paper is to consider - using a case study approach - potential impacts caused by the virus and to identify possible strategic responses for increasing the organizational resilience. We, therefore, seek to address the following research questions in this study: How do organizations respond in terms of strategies to the Covid-19 pandemic in order to increase their resilience?

The structure of the paper is as follows. First, we discuss potential solutions and benefits of new technologies, and we present organizational resilience as a theoretical framework. We then outline the four interviews conducted with the CEOs and we next summarize the main findings. Next, we address how firms can change their strategies to increase the level of organizational resilience in response to the Covid-19 pandemic. Finally, we develop an integrated policy framework aiming at guiding the managerial community in the time of unexpected events.

\section{Theoretical framework}

\subsection{The disruptive effects of Covid-19 pandemic on entrepreneurship}

As discussed in the previous section, the major economic and social consequences deriving from the advent of Covid-19 pandemic quite vary across industries and geographical areas. Since the beginning of the pandemic, more than $70 \%$ of start-ups terminated contracts of full- 
time employees (Fintech, 2020). At the same time, many companies had to establish new partnerships and to convert their expertise, resources and equipment to navigate this new complex scenario in which entrepreneurship is the key (e.g., Giorgio Armani, Gucci). Despite the virus forced almost every country to increase business closing and human distances, there is a growing necessity to be closer and united - at least symbolically (Jani, 2020). In fact, the collaboration enables companies, individuals and institutions to achieve a collective purpose. Coordinating practical efforts is helpful to find effective measures in response to the pandemic. Bacq and Lumpkin (2021) referred to the social entrepreneurship concept to offer theoretical insights on how decisions in time of crises should be cross-sector, either social or non-social. Therefore, the new entrepreneurship model requires a deeper and greater understanding on how social problems need to be addressed. In the face of disasters like Covid-19, the entrepreneurial action deals with psychological conditions, remote connections and resilience (Shepherd, 2020). In any cases, (Maritz et al., 2020) argued that the strategic measures adopted should be proactive to accurately leverage on opportunities. Entrepreneurs can generally refer to cultural aspects to share common values and systems but they can even rely on lifestyle to maintain "a certain way of living" in case of unexpected events (Ratten, 2020, p. 512).

In the following paragraphs, we present the idea of organizational resilience as an ability to overcome environmental changes.

\subsection{The role of organizational resilience in time of unexpected events}

Organizational resilience is considered a crucial issue in the field of strategic management (Vogus and Sutcliffe, 2007). It is represented by the ability to deal with difficulties and environmental turbulence (Buliga et al., 2016; Holling, 1973; Linnenluecke, 2017; Vogus and Sutcliffe, 2007). In case rapid changes occur, resilience is associated with negative outcomes when the organization is rigid in terms of structure and control mechanisms (Buliga et al., 2016). In order to increase the level of resilience, companies can explore the role of organizational ambidexterity and strategic consistency (Iborra et al., 2019). Some other authors (e.g. Sullivan-Taylor and Branicki, 2011) identified the need to be "more strategic and proactive." The ability to respond to unexpected events also depends on the size of the companies (Iborra et al., 2019; Linnenluecke, 2017); for instance, large firms tend to be focused on being prepared for disruptions (Linnenluecke, 2017; Weick and Sutcliffe, 2015), while others implement organizational routines to reduce complexity and uncertainty and be aligned with the external environment (Boisot and Child, 1999; Lengnick-Hall and Beck, 2005). (Lengnick-Hall and Beck, 2005) found that the way in which companies execute specific creative problem-solving routines really influences their likelihood to be more resilient. Other possible responses to increase resilience include boosting certain employee strengths and the development of determining employee abilities, such as confidence and hope (Luthans, 2002).

\subsection{Investments in new technologies: opportunities for growth}

In times of crisis like the Covid-19, the investments in digital technologies characterize a fruitful solution to mitigate the disruptive effects, thus increasing the level of organizational resilience. Despite the difficulty in measuring the value of the digital economy, its size ranges from $4.5 \%$ to $15.5 \%$ of the global GDP, according to UNCTAD (2019). At the individual level, more than 4.5 billion people around the world are represented by Internet users, and almost 4 billion persons are social media users (We Are Social, 2020). At the firm-level, many organizations have already started to direct their strategic investments to the development of digital infrastructures and ICT tools. Moreover, several benefits are associated with the adoption of new technologies like artificial intelligence (AI), blockchain, $5 \mathrm{G}$, drones and the Internet of Things (IoT). For instance, if we refer to AI, we can imagine a wide set of 
applications, ranging from healthcare and public and social sectors to education, and we expect that their implementation can improve the disaster response due to better and faster management of resources. Especially, the collaboration between multiple partners can enhance the synergies linked to the creation of algorithms, and thus avoiding any kinds of useless efforts. Moreover, a McKinsey Global Institute analysis estimates that AI is able to advance the value in many sectors like travel, transport and logistics, and retail, together with automotive, high-tech and oil and gas. In general, the ability of machines is to understand and to run an activity very quickly and in a more efficient way. The dark side of new technologies' application is that the automation could increase fears and uncertainty; for instance, according to McKinsey and Company, $49 \%$ of global work activities are expected to be replaced by machines by 2055 . Furthermore, at the global scale, the economic impact of 5Genabled connectivity will exceed 12 trillion dollars in the next 15 years (Weinberg, 2020). Also, researchers from the Imperial College London estimated that the higher the levels of connectivity, the higher the economy's growth rates; in particular, on average, a $10 \%$ increase in the adoption of mobile broadband causes an increase up to $2.8 \%$ of economic growth implications of modern technology in the COVID-19 epidemic (Edquist et al., 2017).

\subsection{Adoption of new technologies by industry}

We found that extant literature mainly investigated the role of various applications of new technologies in healthcare for combating the Covid-19 pandemic (Frank et al., 2019; Ishack and Lipner, 2020; Kumar et al., 2020a). For instance, Frank et al. (2019) and Kumar et al. (2020) presented the most relevant benefits associated with digital solution in terms of medical prevention, treatment and follow-up, while Kumar et al. (2020b) identified how these technologies can help retailers in providing efficient services in the same sector. Also, Ishack and Lipner (2020) found that the application of 3D printing technology reported advantages for the supply of respirator masks in the same industry. Despite wide research is focused on the medical industry, we adopted the Standard Industrial Classification (SIC codes) to identify how the investments in advanced technologies can be interpreted as a strategy for growing and overcoming the Covid-19 crisis in every sector (Table 1). Furthermore, while (Nicola et al., 2020) summarized the socio-economic effects of the virus in primary, secondary and tertiary sectors, the digital aspect is anything but predominant. In this sense, we start from the assumption that companies operating in different industries can grasp relevant opportunities in the event that unexpected events like the Covid-19 take place. The virus pandemic represents a generalizable context of analysis. Thus, we believe that additional industries like agriculture, manufacturing and public administration can offer interesting insights to explore the role of digital solutions in response to unexpected events.

Even though several authors explored potential responses to the Covid-19 pandemic, yet we found that there is space for emphasizing the role of new technologies in overcoming the crises.

\section{Research methodology}

With the aim to identify and discuss the most challenging transformations as well as potential successful strategic responses to the Covid-19 pandemic, we analyzed four cases. Despite (Yin, 2014) argued that a single case offers depth of information, we decided to provide additional insights by collecting data from four interviews with the CEOs of companies operating in different industries in Italy (Table 2). The selection of four case studies is helpful to explore and understand how different organizations operating in different sectors react to the Covid-19 pandemic in order to safeguard their resilience. Especially, our sample consisted in multiutilities, media, utilities and telecommunications 


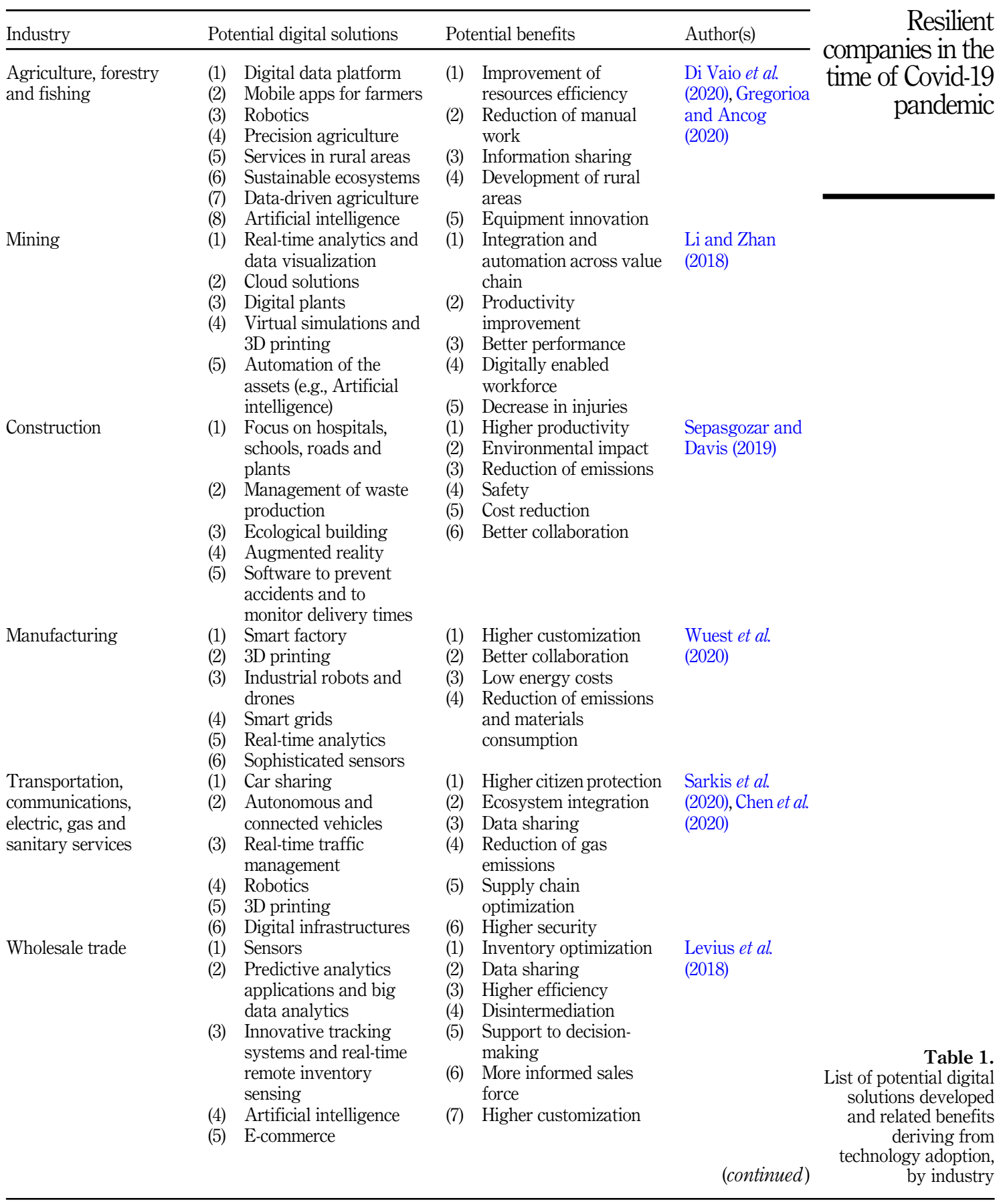




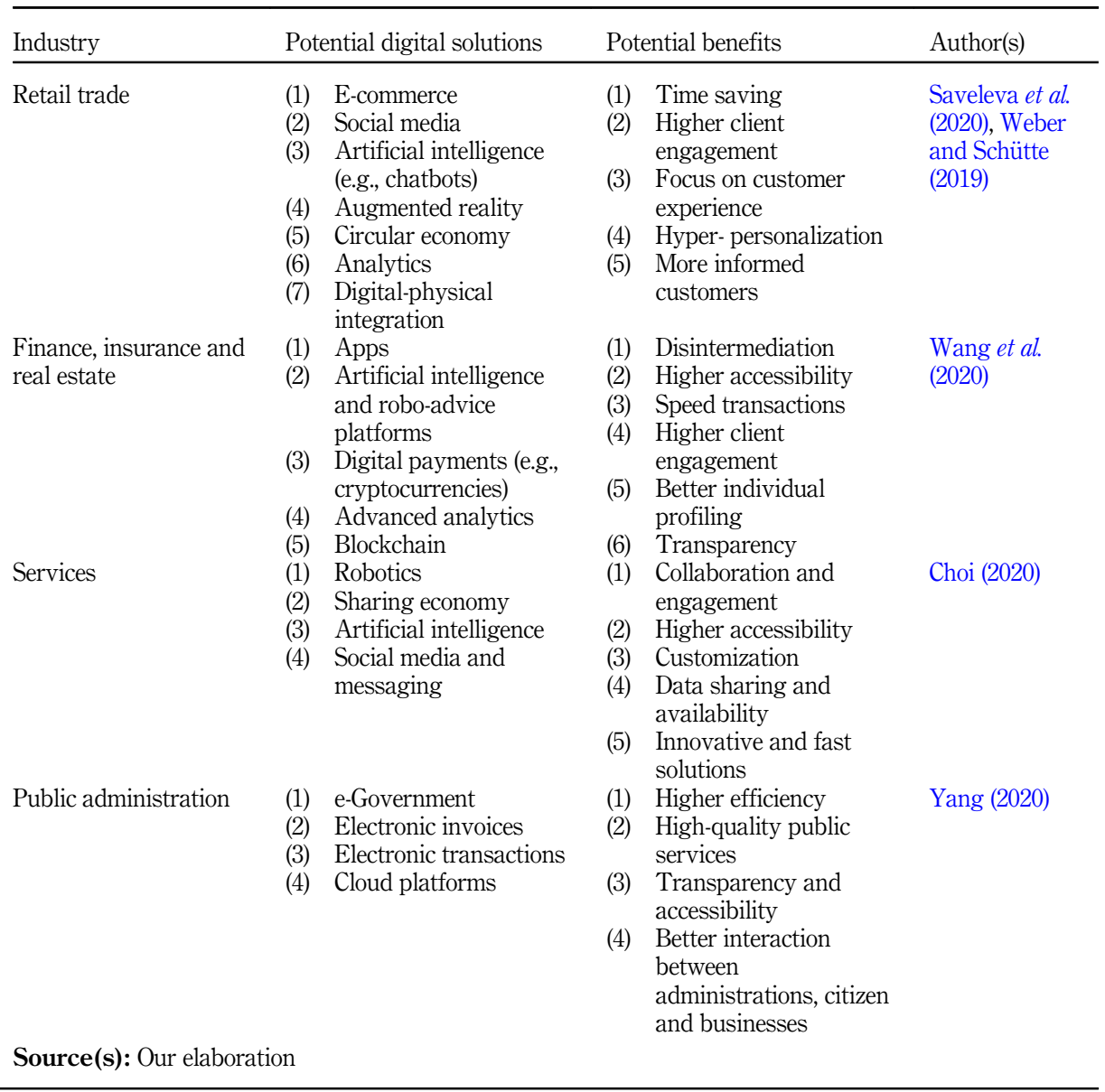

Table 1.

\begin{tabular}{lllll}
\hline & Acea S.p.A. & Sky Italia S.r.l. & A2A S.p.A. & Vodafone Italia S.p.A. \\
\hline Industry & Multiutility & Media & Utilities & Telecommunications \\
Revenues* & $3.186 \mathrm{M} €$ & $3.29 \mathrm{~B} €$ & $7.324 \mathrm{M} €$ & $43,7 \mathrm{M} €$ \\
Employees* & 7.576 & 3.037 & 11.294 & 6.536 \\
Type of & Water, energy & Production and & Production and & Administrative activity \\
services & infrastructure and & distribution of pay- & distribution of & and provision of \\
offered & environmental & per-view digital & electricity; storage & telecommunications \\
& services & channels, pay-per- & of components and & services \\
& & view services and & electrical & \\
& & interactive TV & equipment; & \\
& & services, via & distribution of & \\
& & satellite and cable & natural gas &
\end{tabular}

Table 2.

Characteristics' overview of the four cases studied
Note(s): *2019 data
(1) Time saving
(2) Higher client

engagement

experience

(4) Hyper- personalization

(5) More informed

(1) Disintermediation

(2) Higher accessibility

(3) Speed transactions

Higher client

engagement

vidual

(6) Transparency

(5) Blockchain

(1) Robotics

(2) Sharing economy

(3) Artificial intelligence

Social media and messaging

(3) Customization

availability

1) Higher efficiency

High-quality public

accessibility between administrations, citizen and businesses
Saveleva et al. and Schütte

(2019)

Wang et al.

Choi (2020)

Yang (2020) 
companies. The comparison of the pandemic effects across sectors as well as the variety in terms of subsequent strategies implemented provides interesting insights. Therefore, the organizations selected can be considered appropriate for the study since they compete in various and dynamic environments where the effects of Covid-19 and the related strategic responses are expected to be explored and confronted. Moreover, we believe that the Italian business represents a suitable context due to the significant impact of the virus recorded (e.g., lockdown measures and number of deaths). The Italian context can be generalizable, still contemplating the specific institutional frameworks. Also, the choice of these sectors is justified if we consider the disruptive and considerable consequences provided by the pandemic in terms of revenues, consumer behavior and safety. In this case, the need for organizations to react for increasing the organizational resilience is understandable and deserves an in-depth study. For instance, some analysts estimated that the Covid-19 pandemic could cause up to US\$5bn in losses to the global film industry [2] In relation to the telecommunication industry, 3 billion citizens all around the world are still not connected, and this condition appears even more critical due to the pandemic (International Finance Corporation, 2020) [3].

With regards to the data collection process, the semi-structured interviews served as the primary source of data and CEOs of these companies represented our target. In particular, the semi-structured framework enabled us to capture "all aspects of the practices undertaken" (Landry et al., 2016, p. 431); they were conducted in the period March-June 2020 and were based on questions dealing with the Covid-19 implications. With the aim to explore the level of organizational resilience, each of the CEOs was asked to describe the most important impact of the crisis as well as the most relevant strategic responses planned or adopted. In the following section, we report and discuss the fundamental insights emerged during the data collection process.

\section{Findings}

\subsection{Presentation of the Acea S.p.A. case: interview with manager 1}

At the time of the interview, Manager 1 was the CEO of Acea S.p.A., an Italian multi-utility company, operating in the water, energy and environmental sectors.

Among the different types of responses to the Covid-19 pandemic, the informant emphasized the need to offer protection to every citizen. This finding clearly emerges from the following quote: "The first objective of companies like Acea S.p.A. is to guarantee not only remote connections but also water services in consideration of the increasing health-related needs (e.g., hygiene)." [Interview with Manager 1, April 3rd, 2020]. Therefore, a fast response in time of rapid transformations makes the difference, according to Manager 1. On the one side, the mitigation actions should be adopted for more negative aspects; on the other side, support and sponsorship actions should be assessed for more positive occasions. With regards to Acea S.p.A., an immediate transition to the agile work has been implemented with more than $80 \%$ employees managed remotely. Moreover, every individual has been equipped with the necessary tools (like face masks) to ensure that the safety of the entire workplace is guaranteed. At the same time, while the customer support has been maintained, less important activities has been postponed or discontinued. A specific Crisis Committee, in which the manager of compliance is included, has been chosen to assess and manage the risks and to plan potential response to future crises. More in general, "[ . . . it is essential to build a strong team in peacetime so that it goes well in wartime" [Interview with Manager 1, April 3rd, 2020]. The possibilities to encourage the installment payments, to postpone the user deadlines and to close physical branches in favor of the virtual ones are needed. Not less important is the role of education; in particular, Acea S.p.A. has recently established the Digital Academy to support the development of digital professional skills. The concept of 
fragility is thus opposed to the capability of each organization to be resilient and flexible. Resilience means learn to prevent, to predict, and to plan. After the Covid-19 pandemic, we will become better; there will be evolving ways of working, higher productivity, waste reduction, and finally, better relationships. In the words of our informant: "Smart-working will be adopted only by determined employees' categories since the presence in the field is required for the most operative and indispensable workers who ensure that services are properly distributed" [Interview with Manager 1, April 3rd, 2020].

\subsection{Presentation of the Sky Italia S.r.l. case: interview with manager 2}

At the time of the interview, Manager 2 was the CEO of Sky Italia S.r.l., a company providing television and radio broadcasting services and offering broadcasting paid-television, national and international contents of sports, entertainment, news, documentaries, travel, music, adultand children's channels.

With regards to the effects deriving from the Covid-19 pandemic, companies are forced to be more innovative and even more focused on the simplification process enabled by the digital. In this context, the whole customer experience is redesigned (e.g., one-stop shopping) with the aim to guarantee the quality which always remains "the must." For instance, Manager 2 believes that the premium positioning of Sky Italia S.r.l. needs to be protected and appropriately justified.

In relation to the strategic responses developed, the informant argued that, when disruptive events like the Covid-19 occur, the increasing presence of digital skills within the organization represents a potential driver for growth. Furthermore, the correct monitoring of customer behaviors, in addition to the accurate selection of institutional information without being conditioned by speculative elements - are crucial elements for the reconfiguration of customer journey and touch points. Moreover, the quality of the contents as well as the innovation of the formats is increasingly important.

Nowadays, the number of hours dedicated to digital contents is exponential. Furthermore, the role of entertainment (e.g., shows, TV series) is more and more important, also considering the increasing competition. Therefore, the development of valuable and various contents delivered through a unique digital platform like Sky Italia S.r.l. makes the difference and finally simplify the customers' life [Interview with Manager 2, April 8th, 2020].

After the Covid-19 pandemic, nothing will remain the same: we should be more aware of the transformations, more adaptive and also further collaborative to develop together the television of the future.

\subsection{Presentation of the A2A S.p.A. case: interview with manager 3}

At the time of the interview, Manager 3 was the President of A2A S.p.A., an Italian utility company, active in electricity, gas, district heating, waste, integrated water cycle and public lighting.

With regards to the Covid-19 pandemic's consequences, the virus represents a threat for every industry and a potential opportunity for exploiting innovation (e.g. remote working). Among the most affected advanced technologies, there are digital productions and communications but also energy-related and transports-related applications (e.g., connectivity).

In response to the crisis, the figure of the $\mathrm{CEO}$ is crucial for navigating the complex scenario. According to our informant, "[. . . ] existing risk management activities did not include any crisis plan that is at least adequate for navigating the current pandemic. Therefore, there is the need to define a structured crisis management plan, by taking into account potential disruptive shocks" [Interview with Manager 3, March 26th, 2020]. Of course, the collaboration 
with key partners is relevant, as well; especially, the role of the Chief Financial Officer (CFO) as the person who manages numbers and evaluates their consistency with respect to the vision of the $\mathrm{CEO}$ is crucial. In addition, "the role of government is crucial to encourage the infrastructure investments that are at the service of every citizen and organization" [Interview with Manager 3, March 26th, 2020]. After the Covid-19 diffusion, we will need to have more and more "speed" numbers useful to synthetize business and strategic elements. Moreover, there will be growing phenomena of markets' contraction due to the virus; for instance, companies suffering from the Covid-19 pandemic can decide to merge or acquire in order to reinforce their competitive positioning but also to take advantage from the economies of scale. In consideration of the increasing amount of non-performing loans (NPLs), there is the need to consider also financial aspects like the possible introduction of the Guarantee Fund to cover any NPLs generated by the SMEs. Supportive measures like these can avoid the risk that a health crisis could evolve into a financial one. To summarize, every organization should develop a "visionary leadership" in which short-term actions are reconciled with the most ambitious long-term goals.

\subsection{Presentation of the Vodafone Italia S.p.A. case: interview with manager 4}

At the time of the interview, Manager 4 was the CEO of Vodafone Italia S.p.A., a company providing telecommunication services and offers prepaid, postpaid, data, roaming, mobile, messaging, tariff plans, Internet, broadband and integrated wireless communication services.

Investing in telecommunication infrastructures represents the "must," according to Manager 4. At the same time, due to the increased traffic data diffused both in the mobile and in the fixed networks, it is mandatory to invest in $5 \mathrm{G}$ technology. To do this, it is fundamental to simplify the regulatory framework at national scale in order to ensure flexibility and resilience. In relation to the $5 \mathrm{G}$ development, our informant clearly recommended and suggested that "[...] the entire system as well as the burocratic procedures should be simplified to speed up the fifth-generation technology. In fact, $5 \mathrm{G}$ will become more and more critical in every sector such as life science" [Interview with Manager 4, June 8th, 2020].

After the Covid-19 pandemic, our society will be characterized, on the one hand, by increasing distances, on the other hand by suppressed distances. In relation to this point, the existing global supply chains demonstrated to not be able to overcome the shocks - "they are too vulnerable, indeed" [Interview with Manager 4, June 8th, 2020]. Moreover, geographical and political risks frequently emerge. If we look at the customers' side, the virus will lead to a growing "contactless" economy where the digital represents a useful tool for interactions and processes' optimization. From now on, Vodafone Italia S.p.A. should become a "solution integrator" able to offer, in fact, multiple solutions in terms of seamless customer journey. In this sense, the role of partnerships (e.g., with Microsoft, recently announced) is crucial to innovate and to successfully implement a strategic transformation. Within the company, dedicated meetings are conducted with the aim to exchange opinions about the current situations and to predict future events. With regards to the government, our informant declared that "[...] there is an even stronger relationship between states and economy. Therefore, every leader needs to manage this additional complexity" [Interview with Manager 4, June 8th, 2020]. Finally, with the advent of the Covid-19 pandemic, an increasing level of security is required and the real value of emotional connectivity developed with the colleagues is better understood.

In sum, our analysis highlighted five key areas of strategic intervention in response to the Covid-19 pandemic: financial support, new sanitary norms, new business models and new business systems, digital investments and support to education. Indeed, by dedicating resources to physical and digital infrastructures, by reconfiguring the existing ways in which companies do business and by increasing the overall safety and education of citizens' 
JEPP

organizations can also increase resilience and flexibility. The following Figure 1 summarizes our data structure and the main strategic aggregate dimensions emerging from our analysis.

\section{Discussion}

Summarizing the main insights and contributions of the informants, we found that the role of digital technologies is decisive in developing effective responses to crises like the Covid-19 pandemic. In this sense, our starting assumption appeared to be well-proven. One crucial aspect emerged from the interviews is related to the ability to distinguish between short-term actions and long-term decisions to accurately capture potential opportunities from the crisis. Most of the informants focused on the development of digital skills useful to navigate the complex scenario. Again, a strong association between digital solutions investments and positive strategic responses to unexpected events is associated with the higher level of organizational resilience. Also, while the financial aspects are particularly felt by Manager 3 and Manager 4, Manager 1 mostly emphasized the human side related to the management of the crises. All of the interviewees agreed on the need to ensure quality and delivery of the offering and the informants also claimed that cooperating through partnerships or team working can help to compete in the present but also to make the difference in the future.

Starting from the data collected, we aim at setting out a potential structure of integrated policy framework to develop short-term and long-term measures, and thus to implement a generalizable recovery plan in response to the Covid-19 pandemic. Each informant was asked

\section{Strategic actions}

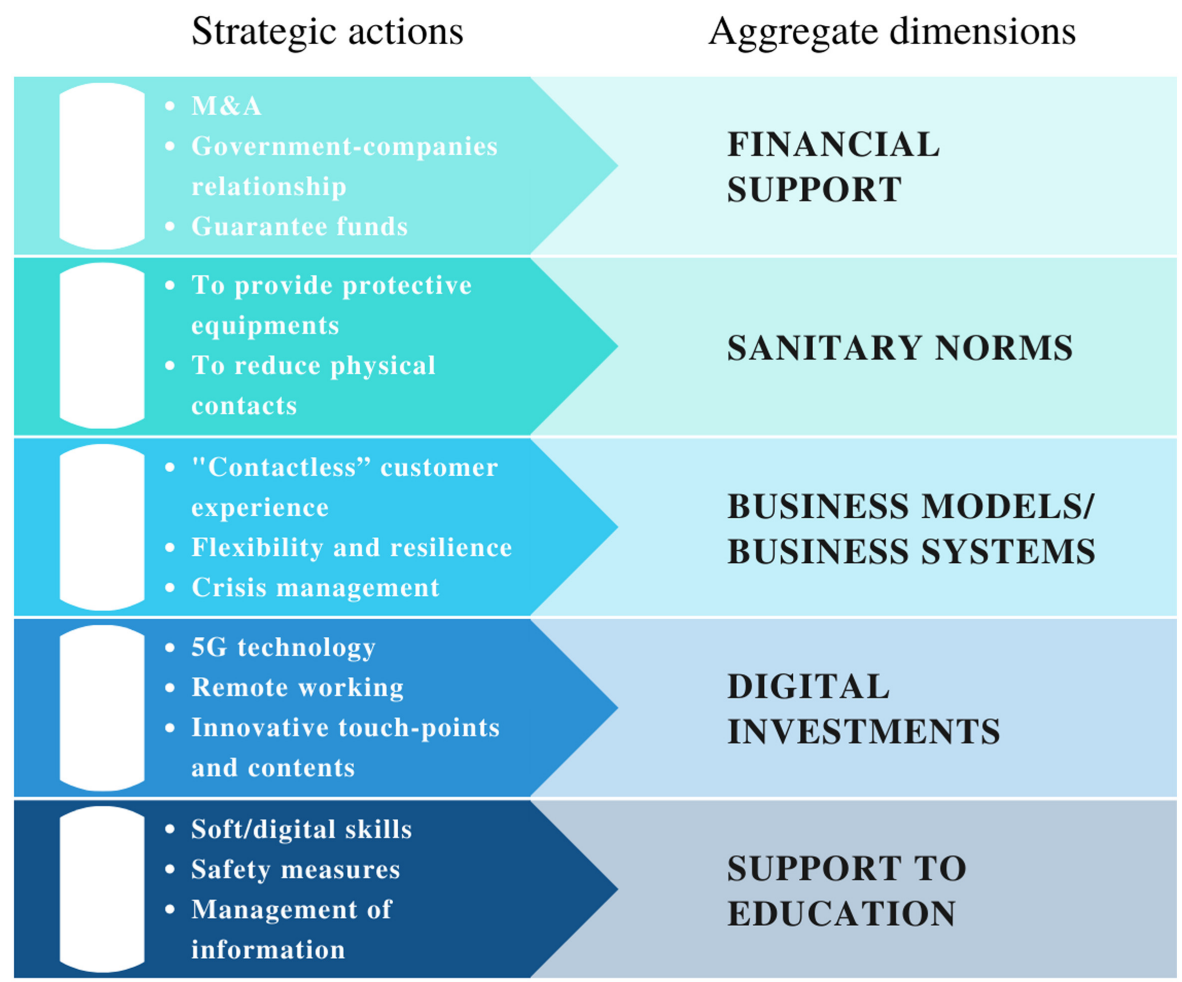

Source(s): Our elaboration
Figure 1.

Data structure reproduced on the basis of the interviews

Source(s). Onr elaboration 
to describe the organization's most important strategic responses to the virus. The interviews revealed that the financial support represents one of the main priorities to protect the citizens and to strengthen the assets of both small and medium enterprises and big companies. To support the business, certain institutional policies are needed. For instance, OECD (2020) suggested to increase liquidity and to provide income support to households; in addition, governments could consider the deferment of tax and VAT payments and incentives in terms of digital investments. Second, the health crisis of Covid-19 called for new sanitary norms regulating the job places that should be even stricter and aligned with the international standards in terms of safety and protection. In this sense, every organization should aspire to be a "safe organization to work in and with" from now on. Third, new business models and new business systems should be configured to become resilient to possible unexpected events often surprising the organizations (Linnenluecke, 2017) and to offer sustainable and innovative products and services. Generating new procurement alternatives and implementing new ways of doing business (e.g., smart-working) can both represent valid answers to the crises. Strategies like re-shoring and supply chain shortening have been evaluated and executed since the Covid-19 has been spread. The interviews showed that digital investments represent a key strategy to navigate this complex scenario. Anyway, to realize the full potential of new technologies adoption, it is mandatory to encourage the general access to digital infrastructures, services and data. As suggested by OECD (2019), each person will possess three connected devices by 2022; nevertheless, still too many countries record a digital gap, and they need to work more on supporting the diffusion of digital tools. If we look at the job market, it is also crucial to develop distance learning and digital skills in order to navigate the risks associated with Covid-19. Finally, as systems massively move to e-learning, it is crucial to guarantee access equality as well as high skill levels. According to WEF, almost $15 \%$ of the global workforce will have to change jobs or, alternatively, to acquire new skills by 2030 . Therefore, support to education of human capital must be accelerated and directed above all toward the adaptation and flexibility of individuals, and the development of technological skills, creativity, innovation, emotional intelligence and data management. Finally, based on our four cases, we are able to consider the role of potential institutional constraints in driving the change and in navigating the crises. Therefore, a constant dialoge between business and institutions should emerge even if frequently difficult to be assessed (Herrera-Echeverri et al., 2014).

\section{Policy implications}

The response to unexpected events like Covid-19 pandemic has to be global. The execution of the strategies discussed by our informants entails a strong cooperation between institutions, companies, universities and private actors. Therefore, the policies adopted can be either public, strategic and operational (Weible et al., 2020). Among several public policies, partial closures or stringent lockdowns can be planned. Mitigating strategic and operational measures can include crisis management, the inclusion of medical personnel or emergency managers, as well as the creation of dedicated committees and departments.

The most important lesson of the Covid-19 pandemic is that national governance arrangements are extremely diverse across the world. Moreover, a unique effective model does not exist since it strongly depends on local characteristics. Despite these differences, specific integrated and collective actions such as the accountability, the communication and transparency among partners and the technology adoption are crucial.

\section{Conclusions and future research}

The aim of the paper is to discuss and reflect on the ability of specific companies to increase their level of organizational resilience, when unexpected events happen. In offering an 
integrated policy framework that summarized the most relevant strategic responses to be adopted, we follow Peng et al. (2009, p. 73) in affirming that the institution-based view offers "interesting insights" on how firm-level strategy-making processes and both rulers and economic outcomes can be connected. In this sense, we emphasize the need to consider potential institutional issues in developing a successful strategy of organizational resilience. Therefore, future studies can investigate whether the cooperation between business and institutional levels encourages the possibility to harness significant opportunities in case of unexpected events. In particular, the role of institutional proximity can be evaluated to understand whether organizations with similar institutional elements tend to respond similarly to the crises. For instance, does the formation of strategic alliances affect the likelihood that the organizational resilience is increased? In this case, comparative analyses based on different types of industries and institutional frameworks can provide promising insights.

A remarkable result collected from the interviews is the ability to respond to the Covid-19 pandemic with an accurate planning to assess and manage risks. In fact, an inadequate risk assessment regarding the urgency of the situation can led to a rapid global spread of the virus (Peeri et al., 2020). In order to accurately define a set of potential risks threatening the organizational resilience, the entire decision-making process needs to be redefined taking into consideration critical functions and services, important values and reallocation potentials. In particular, due to the advent of big data, the phase of "analysis" of decision-making has become intricate (Acciarini et al., 2020). For this reason, among a wide set of data, each information need to be validated with the aim to select the most relevant evidence. Therefore, in the event that crises like the Covid-19 occur, how big data can play a positive role in increasing the level of organizational resilience?

To sum, we recommend that an incisive policy framework able to amplify the organizational resilience should consider: financial support, definition of new sanitary norms, development of new business models and new business systems, digital investments and support to education. Furthermore, building and powering a valuable network of stakeholders (e.g. public-private partnerships) is fundamental to shape an integrated policy approach. Therefore, this study increases our knowledge on organizational resilience theory and offers the managerial community a framework of potential strategic responses to overcome crises like the Covid-19 pandemic.

The speed of reactions in response to the current rapidly evolving epidemic is the key, like China and South Korea demonstrated in the last months (e.g. by adopting apps for detecting people in close contact with Covid-19 cases). The sense of collaboration between business and institutions should be increased, so that the virus can be fought together and the fragile economy can recover. From now on, nothing will be the same anymore.

\section{Notes}

1. VIX is a closely watched measure of volatility in US stocks.

2. https://www.hollywoodreporter.com/news/film-industry-facing-5-billion-loss-coronavirusoutbreak-1282038

3. The International Finance Corporation is a World Bank Group.

\section{References}

Acciarini, C., Brunetta, F. and Boccardelli, P. (2020), "Cognitive biases and decision-making strategies in times of change: a systematic literature review", Management Decision, Vol. 59, doi: 10.1108/ MD-07-2019-1006. 
Africa Union (2021), Africa CDC Dashboard.

Resilient

Bacq, S. and Lumpkin, G.T. (2021), "Social entrepreneurship and COVID-19", Journal of Management Studies, Vol. 58 No. 1, pp. 285-288.

Baek, S., Mohanty, S.K. and Glambosky, M. (2020), "COVID-19 and stock market volatility: an industry level analysis", Finance Research Letters, Vol. 37, p. 101748.

Bloomberg (2020), China Car Sales Drop Record 80\% As Virus Empties Showrooms.

Boisot, M. and Child, J. (1999), "Organizations as adaptive systems in complex environments: the case of China”, Organization Science, Vol. 10 No. 3, pp. 237-252.

Buliga, O., Scheiner, C.W. and Voigt, K.-I. (2016), "Business model innovation and organizational resilience: towards an integrated conceptual framework", Journal of Business Economics, Vol. 86 No. 6, pp. 647-670.

Chen, C.F., de Rubens, G.Z., Xu, X. and Li, J. (2020), "Coronavirus comes home? Energy use, home energy management, and the social-psychological factors of COVID-19", Energy Research and Social Science, Vol. 68, 101688, doi: 10.1016/j.erss.2020.101688.

Choi, T.-M. (2020), "Innovative "Bring-Service-Near-Your-Home" operations under Corona-Virus (COVID-19/SARS-CoV-2) outbreak: can logistics become the Messiah?", Transportation Research Part E: Logistics and Transportation Review, Vol. 140, 101961, ISSN: 1366-5545.

Continetti, M. (2020), "The social costs of COVID-19", National Review.

Di Vaio, A., Boccia, F., Landriani, L. and Palladino, R. (2020), "Artificial intelligence in the agri-food system: rethinking sustainable business models in the COVID-19 scenario", Sustainability, Vol. 12 No. 12 , p. 4851.

Edquist, H., Goodridge, P., Haskel, J., Li, X. and Lindquist, E. (2017), How Important Are Mobile Broadband Networks for the Global Economic Development?, Working Paper, Imperial College Business School, pp. 1744-6783.

Eurostat (2020), Industrial Production Up by 9.1\% in Both Euro Area and EU.

Fintech (2020), Impact of COVID-19 Crisis: Insights From Global Startup Survey.

Frank, A.G., Dalenogare, L.S. and Ayala, N.F. (2019), "Industry 4.0 technologies: implementation patterns in manufacturing companies", International Journal of Production Economics, Vol. 210, pp. 15-26.

Gregorioa, G.B. and Ancog, R.C. (2020), "Assessing the impact of the COVID-19 pandemic on agricultural production in southeast Asia: toward transformative change in agricultural food systems", Asian Journal of Agriculture and Development, Southeast Asian Regional Center for Graduate Study and Research in Agriculture (SEARCA), Vol. 17 No. 1.

Haren, P. and Simchi-Levi, D. (2020), "How coronavirus could impact the global supply chain by midmarch", Harvard Business Review.

Herrera-Echeverri, H., Haar, J. and Estévez-Bretón, J.B. (2014), "Foreign direct investment, institutional quality, economic freedom and entrepreneurship in emerging markets", Journal of Business Research, Vol. 67 No. 9, pp. 1921-1932.

Holling, C.S. (1973), "Resilience and stability of ecological systems", Annual Review of Ecology and Systematics, Annual Reviews, Vol. 4 No. 1, pp. 1-23.

Iborra, M., Safón, V. and Dolz, C. (2019), "What explains resilience of SMEs? Ambidexterity capability and strategic consistency", Long Range Planning, Vol. 53, p. 101947.

International Finance Corporation (2020), COVID-19's Impact on the Global Telecommunications Industry.

International Labor Organization (2020), COVID-19 and the World of Work: Impact and Policy Responses, 1st ed., ILO Monitor.

International Monetary Fund (2021), Policy Support and Vaccines Expected to Lift Activity. 
Ishack, S. and Lipner, S.R. (2020), "Applications of 3D printing technology to address COVID-19related supply shortages", The American Journal of Medicine, Vol. 133 No. 7, pp. 771-773.

Jani, B. (2020), From Me to We: COVID-19 Heralds a New Model of Entrepreneurship, World Economic Forum, Basel.

Kumar, A., Gupta, P.K. and Srivastava, A. (2020a), "A review of modern technologies for tackling COVID-19 pandemic", Diabetes and Metabolic Syndrome: Clinical Research Reviews, Vol. 14 No. 4, pp. 569-573.

Kumar, M.S., Raut, D.R.D., Narwane, D.V.S. and Narkhede, D.B.E. (2020b), "Applications of industry 4.0 to overcome the COVID-19 operational challenges", Diabetes and Metabolic Syndrome: Clinical Research Reviews, Vol. 14 No. 5, pp. 1283-1289.

Landry, S., Beaulieu, M. and Roy, J. (2016), "Strategy deployment in healthcare services: a case study approach", Technological Forecasting and Social Change, Vol. 113, pp. 429-437.

Lengnick-Hall, C.A. and Beck, T.E. (2005), "Adaptive fit versus robust transformation: how organizations respond to environmental change", Journal of Management, Vol. 31 No. 5, pp. 738-757.

Levius, S., Safa, M. and Weeks, K. (2018), "Information and communication technology strategies to improve international competitiveness in the wholesale and retail trade sector", International Journal of Business and Globalisation, Vol. 20 No. 1, doi: 10.1504/IJBG.2018.088680.

Li, J. and Zhan, K. (2018), "Intelligent mining technology for an underground metal mine based on unmanned equipment”, Engineering, Vol. 4 No. 3, pp. 381-391, ISSN 2095-8099.

Linnenluecke, M.K. (2017), "Resilience in business and management research: a review of influential publications and a research agenda: resilience in business and management research", International Journal of Management Reviews, Vol. 19 No. 1, pp. 4-30.

Luthans, F. (2002), "The need for and meaning of positive organizational behavior", Journal of Organizational Behavior, Vol. 23 No. 6, pp. 695-706.

Maritz, A., Perenyi, A., de Waal, G. and Buck, C. (2020), "Entrepreneurship as the unsung hero during the current COVID-19 economic crisis: Australian perspectives”, Sustainability, Vol. 12 No. 11, p. 4612.

Nicola, M., Alsafi, Z., Sohrabic, C., Kerwan, A., Al-Jabir, A., Iosifidis, C., Agha, M. and Agha, R. (2020), "The socio-economic implications of the coronavirus pandemic (COVID-19): a review", International Journal of Surgery, Vol. 78, pp. 185-193.

OECD (2019), Enhancing Access and Connectivity to Harness Digital Transformation.

OECD (2020), The Territorial Impact of COVID-19: Managing the Crisis Across Levels of Government.

Peeri, N.C., Shrestha, N., Rahman, M.D., Siddikur, Zaki, R., Tan, Z., Bibi, S., Baghbanzadeh, M., Aghamohammadi, N., Zhang, W. and Haque, U. (2020), "The SARS, MERS and novel coronavirus (COVID-19) epidemics, the newest and biggest global health threats: what lessons have we learned?", International Journal of Epidemiology, Vol. 49 No. 3, pp. 717-726.

Peng, M.W., Sun, S.L., Pinkham, B. and Chen, H. (2009), "The institution-based view as a third leg for a strategy tripod”, Academy of Management Perspectives, Vol. 23 No. 3, pp. 63-81.

Ratten, V. (2020), "Coronavirus (covid-19) and entrepreneurship: changing life and work landscape", Journal of Small Business and Entrepreneurship, Vol. 32 No. 5, pp. 503-516.

Sarkis, J., Cohen, M.J., Dewick, P. and Schröder, P. (2020), “A brave new world: Lessons from the COVID-19 pandemic for transitioning to sustainable supply and production", Resources, Conservation, and Recycling, Vol. 159, 104894, doi: 10.1016/j.resconrec.2020.104894.

Saveleva, N.A., Erdakova, V.P., Ugriumov, E.S. and Yudina, T.A. (2020), "The role of the digital economy in the retail sphere", in Popkova, E. and Sergi, B. (Eds), Artificial Intelligence: Anthropogenic Nature vs. Social Origin. ISC Conference - Volgograd 2020. Advances in Intelligent Systems and Computing, Vol. 1100, Springer, Cham, doi: 10.1007/978-3-030-393199_11.

Schwab, J. (2020), Fighting COVID-19 Could Cost 500 Times as Much as Pandemic Prevention Measures, World Economic Forum. 
Scott, A., Tan, B.YQ., Huak, C.Y., Sia, C., Xian, C.Y., Goh, E.T., Zbikowska, G., Dykowska, G., Martin, G., Kinross, J., Przybylowicz, J., Fedorowski, J., Beatty, J.W., Clarke, J., Sim, K., Abhiram, K., Flott, K., Lim, L.J.H., Wells, M., Denning, M., Almonte, M.T., Tan, M., Mason, S., Purkayastha, S., Yalamanchili, S., Markar, S., Ooi, S.BS., Chidambaran, S., Lifeng, T., Sharma, V.K. and Sounderajah, V. (2020), "Determinants of burnout and other aspects of psychological well-being in healthcare workers during the COVID-19 pandemic: a multinational cross-sectional study", MedRXiv.

Sepasgozar, S.M.E. and Davis, S. (2019), "Digital construction technology and job-site equipment demonstration: modelling relationship strategies for technology adoption”, Buildings, Vol. 9 No. 7, p. 158, doi: 10.3390/buildings9070158.

Shepherd, D.A. (2020), “COVID 19 and entrepreneurship: time to pivot?", Journal of Management Studies, Vol. 57 No. 8, pp. 1750-1753.

Statista (2020), Year-on-Year Change of Weekly Flight Frequency of Global Airlines from January 6 to January 4, 2021, by Country.

Sullivan-Taylor, B. and Branicki, L. (2011), "Creating resilient SMEs: why one size might not fit all", International Journal of Production Research, Vol. 49 No. 18, pp. 5565-5579.

Torales, J., O’Higgins, M., Castaldelli-Maia, J.M. and Ventriglio, A. (2020), "The outbreak of COVID-19 coronavirus and its impact on global mental health", International Journal of Social Psychiatry, Vol. 66 No. 4, pp. 317-320.

United Nations (2020), Policy Brief: A Disability-Inclusive Response to COVID-19.

UNCTAD (2019), Digital Economy Report. Value Creation and Value Capture: Implications for Developing Countries.

UNCTAD (2020), Global Tourism Sector set to lose at least $\$ 1.2$ trillion due to Coronavirus, UNCTAD says. Press release, available at: https://unctad.org/es/node/20435.

Vogus, T.J. and Sutcliffe, K.M. (2007), "Organizational resilience: towards a theory and research agenda", 2007 IEEE International Conference on Systems, Man and Cybernetics, presented at the 2007 IEEE International Conference on Systems, Man and Cybernetics, Montreal, QC, Canada, IEEE, pp. 3418-3422.

Wang, Y., Zhang, D., Wang, X. and Fu, Q. (2020), "How does COVID-19 affect China's insurance market?", Emerging Markets Finance and Trade, Vol. 56 No. 10, pp. 2350-2362.

We Are Social (2020), Digital in 2020.

Weber, F.D. and Schütte, R. (2019), "State-of-the-art and adoption of artificial intelligence in retailing", Digital Policy, Regulation and Governance, Vol. 21 No. 3, pp. 264-279.

Weible, C.M., Nohrstedt, D., Cairney, P., Carter, D.P., Crow, D.A., Durnov, A.P., Heikkila, T., Ingold, K., McConnell, A. and Stone, D. (2020), "COVID-19 and the policy sciences: initial reactions and perspectives”, Policy Sciences, Vol. 53 No. 2, pp. 225-241.

Weick, K.E. and Sutcliffe, K.M. (2015), Managing the Unexpected: Sustained Performance in a Complex World, 3rd ed., Wiley, Hoboken, New Jersey.

Weinberg, A.S. (2020), Here's How the US Can Get the Best Out of 5G, World Economic Forum.

World Health Organization (2021), Coronavirus (COVID-19) Dashboard.

Wuest, T., Kusiak, A., Dai, T. and Tayur, S.R. (2020), "Impact of COVID-19 on manufacturing and supply networks - the case for AI-inspired digital transformation (May 5, 2020)", available at: https://ssrn.com/abstract $=3593540$ or http://dx.doi.org/10.2139/ssrn.3593540.

Yang, K. (2020), "Unprecedented challenges, familiar paradoxes: COVID-19 and governance in a new normal state of risks", Public Administration Review, Advance online publication, doi: 10.1111/ puar.13248.

Yin, R.K. (2014), Case Study Research: Design and Methods, 5th ed., SAGE, Los Angeles. 


\section{About the authors}

Chiara Acciarini is Ph.D. Candidate in Management at Luiss University - Rome, Italy - where she also held cum laude the master's degree in Management. She is Research Fellow at the Research Centre for Business Transformation (ReBoot), Luiss Business School, and she is Teaching Assistant to Corporate Strategies, Luiss University. She supports the Global Family Business Management Executive Programme, Luiss Business School and the Management and Governance of Family Firms Masters' Course, Luiss. Her research interests include strategic change and digital expertise of the board. Chiara Acciarini is the corresponding author and can be contacted at: cacciarini@luiss.it

Paolo Boccardelli is Dean at Luiss Business School, Director of the Research Centre for Business Transformation, Luiss Business School and Professor of Management and Corporate Strategy at Luiss in Rome. He is also CEO, Amsterdam Fashion Academy. Paolo sits on many advisory boards, steering groups and committees, both in Italy and further afield, including EFMD where he is a member of the EQUIS Committee and an Advisor of Quality Services and Processes to schools going through EQUIS accreditation for the first time. He is Designated Expert of International standing at the Australian Research Council, Chairman of the Advisory Board of the Lars Magnus Ericsson Foundation, Member of the International Advisory Board, Leeds University Business School and of the UPF Barcelona School of Management. Paolo is expert of leadership and author of many scholarly publications in the field of strategic management, creative industries and business model innovation. Renowned speaker at International Conferences, he wrote the heading "Creative Industries" of the Palgrave Dictionary on Strategic Management.

Mario Vitale is Director of Business Development, Stakeholder Engagement and External Relations at Luiss Business School, Strategic Advisor to General Manager for Corporate Relations and Post-Doc Researcher at Luiss University. He identifies and develops new business opportunities, manages relations with key corporate partners (e.g., Poste Italiane, CDP, ENI, ENEL, IBM, Leonardo, FS, ACEA), and involves them in the development of learning activities, identifying and developing placement opportunities for students. He organizes events for C-level (e.g., Italian Banking Conference 2017-20182019), develops and executes communication strategy (e.g.: editorial plane, social media management), and manages relations with Alumni Association. Speaker at the 3rd Annual Mack Institute Emerging Scholar Workshop, he holds a Ph.D. in Management at the Luiss University.

For instructions on how to order reprints of this article, please visit our website:

www.emeraldgrouppublishing.com/licensing/reprints.htm Or contact us for further details: permissions@emeraldinsight.com 